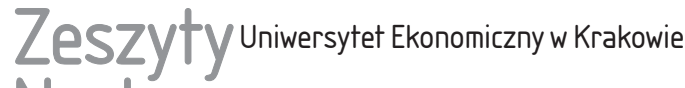 Naukowe
}

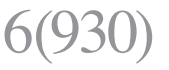

ISSN 1898-6447

Zesz. Nauk. UEK, 2014; 6 (930): 73-86 DOI: 10.15678/ZNUEK.2014.0930.0605

\author{
Marcin Salamaga \\ Katedra Statystyki \\ Uniwersytet Ekonomiczny w Krakowie
}

Krzysztof Sala

Katedra Ekonomii i Polityki Gospodarczej

Uniwersytet Pedagogiczny w Krakowie

\section{Badanie efektywności inwestycji w złoto za pomocą metody TRB}

\section{Streszczenie}

Zakup złota uważany jest za względnie pewną lokatę kapitału, gdyż siła nabywcza tego kruszcu na ogół nie wykazuje tendencji do zmniejszania się w dłuższym okresie. Powstaje jednak pytanie, czy i na ile inwestycja w złoto fizyczne może być dochodowa w krótkim terminie. Niniejszy artykuł można uznać za próbę odpowiedzi na to pytanie.

Celem pracy jest zbadanie, czy cenę złota można badać za pomocą narzędzi analizy technicznej i czy możliwe jest osiągnięcie ponadprzeciętnych dochodów z inwestycji w złoto w krótkim okresie, a w efekcie - zweryfikowanie hipotezy o efektywności rynku złota inwestycyjnego w słabym sensie. W artykule zastosowano popularną w analizie technicznej metodę zasięgu przebicia (trading range break - TRB). Umożliwiło to wyznaczenie rozkładów warunkowych stóp zwrotu z inwestycji w złoto. Efektywność inwestycji w złoto została zweryfikowana przez zastosowanie testu istotności $t$-Studenta dla warunkowych stóp zwrotu i oczekiwanej stopy zwrotu, testu efektywności poza próbą oraz przez porównanie wyników inwestowania cyklicznego ze strategią „kup i trzymaj”.

Słowa kluczowe: złoto, inwestycje finansowe, analiza techniczna, test $t$-Studenta. 


\section{Wprowadzenie}

Zakup złota uważany jest za względnie pewną lokatę kapitału, gdyż siła nabywcza tego kruszcu na ogół nie wykazuje tendencji do zmniejszania się w dłuższym okresie. Ogólnie przyjmuje się, że złoto jest szczególnie bezpieczną lokatą w okresie niestabilnej sytuacji ekonomicznej, kryzysów gospodarczych, niepokojów społecznych czy konfliktów zbrojnych [Pring 1998]. Na rynku złoto występuje przede wszystkim w postaci wyrobów jubilerskich, numizmatów oraz tzw. złota inwestycyjnego. Cena tej pierwszej formy kruszcu jest wypadkową kilku czynników: wartości samego kruszcu, kunsztu artystycznego wyrobu, niepowtarzalności wzoru czy renomy jubilera. Wartość numizmatu z kolei zależy m.in. od stanu waloru, zawartości złota w monecie czy jej wartości historycznej i kolekcjonerskiej.

$\mathrm{W}$ artykule skupiono się na trzeciej z wymienionych postaci kruszcu, czyli fizycznym złocie inwestycyjnym, którego cena wynika z relacji pomiędzy rynkową podażą i popytem na złoto. Fizyczne złoto inwestycyjne można spotkać w postaci sztabek oraz monet bulionowych. O cenie złota decyduje wiele czynników, spośród których można wymienić: ograniczone zasoby występowania i koszty wydobycia kruszcu, zapotrzebowanie przemysłu na ten metal, sytuację gospodarczą i polityczną na świecie oraz zapotrzebowanie banków centralnych na złoto [Pring 1998].

Inwestując w złoto, należy spodziewać się dochodów przede wszystkim w długim horyzoncie czasowym. Powstaje jednak pytanie, czy i na ile inwestycja w złoto fizyczne może być dochodowa w krótkim terminie. Problem ten nie został w sposób jednoznaczny rozstrzygnięty w literaturze przedmiotu. Niniejszy artykuł można uznać za próbę odpowiedzi na to pytanie. Celem tego opracowania jest zbadanie, czy cena złota może być badana za pomocą narzędzi analizy technicznej i czy możliwe jest osiągnięcie ponadprzeciętnych dochodów z inwestycji w złoto w krótkim okresie. To z kolei umożliwi zweryfikowanie hipotezy o efektywności rynku złota inwestycyjnego w słabym sensie. W badaniach zastosowano metodę zasięgu przebicia (trading range break - TRB). Jest ona obok metody średniej kroczącej jedną z częściej stosowanych metod analizy technicznej z uwagi na wysoką efektywność potwierdzoną w badaniach rynków kapitałowych (por. [Hudson, Dempsey i Keasey 1996, Coutts i Cheung 2000, Chang i in. 2004, Coutts 2010]. Implementacja metody TRB umożliwiła wyznaczenie rozkładów warunkowych stóp zwrotu z inwestycji w złoto. Z kolei zastosowanie odpowiednich testów statystycznych pozwoliło na ocenę efektywności strategii wykorzystujących inwestowanie cykliczne. $Z$ uwagi na niespełnienie założeń co do normalności rozkładu stóp zwrotu, wyniki klasycznych testów statystycznych uzupełniono o wyniki testu efektywności poza próbą. Dało to podstawy do wyja- 
śnienia ewentualnych ponadprzeciętnych zysków z cyklicznej inwestycji w złoto. Efektywność inwestowania cyklicznego oceniono również w długim horyzoncie czasowym. W tym celu porównano zyskowność metody zasięgu przebicia ze strategią „,kup i trzymaj”. Można przyjąć, że metoda TRB będzie efektywna w długim okresie, jeśli okaże się lepsza od strategii „kup i trzymaj”.

W niniejszym artykule dokonano krótkiego przeglądu literatury poświęconej badaniom inwestycji w złoto, następnie przedstawiono opis metody badawczej, której wyniki zaprezentowano i zinterpretowano w kolejnym punkcie. Ważniejsze konkluzje odnoszące się celów badania przedstawiono w podsumowaniu. Obliczenia przeprowadzono na podstawie danych $\mathrm{z}$ fixingu cen złota w Londynie z okresu 2.01.1991-21.05.2013 ${ }^{1}$.

\section{Charakterystyka kierunków badań inwestycji w złoto}

W literaturze naukowej poświęconej inwestycjom w złoto znaczny udział mają badania dotyczące modelowania szeregów czasowych cen złota (stóp zwrotu) z naciskiem na prognozowanie. Problematyka ta jest względnie często eksplorowana za pomocą narzędzi współczesnej ekonometrii finansowej. Z uwagi na charakter przebiegu szeregów czasowych stóp zwrotu z inwestycji w złoto i niejednorodność zmienności tych stóp w czasie, często bada się je, wykorzystując modele klasy GARCH (np. [Mensi i in. 2013]). W analizie dynamicznych zależności cen złota i innych wskaźników makroekonomicznych wykorzystywane są także modele wektorowej autoregresji (por. [Lee i in. 2013, Singh i Kishor 2014]).

W polskiej literaturze naukowej analiza ceny złota jest zagadnieniem często podejmowanym przez badaczy zarówno w kontekście określenia tendencji na rynkach surowcowych, jak i możliwości inwestycji w ten metal szlachetny (np. [Borowski 2008, Filipowicz 2010, Bachowski, Kudełko i Wirth 2011]).

Swego rodzaju alternatywą dla ekonometrycznych modeli stosowanych do krótkoterminowych prognoz ruchów cen złota (stóp zwrotu) mogą być narzędzia analizy technicznej. Okazuje się jednak, że metody analizy technicznej w badaniu cen złota są stosowane dość rzadko, i to przeważnie w odniesieniu do instrumentów finansowych rozliczanych na bazie ceny złota (np. kontraktów futures na złoto). Najwięcej przykładów tego typu można znaleźć zwykle w krótkich artykułach prasowych, komentarzach czy opiniach analityków giełdowych prezentowanych w szeroko rozumianej publicystyce ekonomicznej (np. [Duke 2004]). Warsztat naukowy takich opracowań jest na ogół bardzo skromny, m.in. z powodu braku wsparcia metod statystyki matematycznej, które pozwoliłby na ocenę istot-

${ }^{1}$ http://www.goldfixing.com/ (data dostępu: 21.05.2013). 
ności wyników i ewentualne ich uogólnienie. Interesujące przykłady stosowania analizy technicznej złota pojawiają się też w szerszym kontekście badań rynków surowcowych (por. [Górska 2011]).

W zakresie implementacji narzędzi analizy technicznej i metod wnioskowania statystycznego zdecydowanie bardziej popularnym przedmiotem badań od złota są wskaźniki rynków finansowych, takie jak indeksy giełdowe, ceny akcji itp. (por. [Brock, Lakonishok i LeBaron 1992, Hudson, Dempsey i Keasey 1996, Isakov i Hollistein 1999, Coutts i Cheung 2000, Chang i in. 2004, Coutts 2010]). Być może wynika to z faktu, że złoto jest rzadziej postrzegane przez inwestorów jako krótkoterminowa lokata, natomiast narzędzia analizy technicznej są przeważnie wykorzystywane właśnie w krótkookresowym horyzoncie inwestycyjnym.

Deficyt pełnowartościowych analiz naukowych dotyczących efektywności krótkoterminowych inwestycji w złoto stwarza więc szerokie pole do prowadzenia badań w tym obszarze. Uwzględniając cel badawczy niniejszego opracowania, zdecydowano się na zastosowanie w nim narzędzi analizy technicznej, uzupełniając jednak otrzymane rezultaty o wyniki odpowiednich testów istotności.

\section{Metoda badania}

Do identyfikacji sygnałów kupna bądź sprzedaży złota zastosowano metodę zasięgu przebicia (TRB). Pojęcie zasięgu przebicia dotyczy tzw. poziomów wsparcia i oporu. Poziom oporu (wsparcia) można zdefiniować jako lokalne maksimum (minimum) obliczone z cen złota w kolejnych okresach (np. dniach). Generowanie sygnału kupna następuje wówczas, gdy cena złota przewyższa poziom oporu, natomiast sygnał sprzedaży jest generowany, gdy cena złota jest niższa od poziomu wsparcia. Metodę zasięgu przebicia można więc przedstawić następująco [Campbel 2011]:

$$
\begin{gathered}
P_{t}>\max \left\{P_{t-1}, P_{t-2}, \ldots, P_{t-n}\right\}-\text { sygnał kupna, } \\
P_{t}<\min \left\{P_{t-1}, P_{t-2}, \ldots, P_{t-n}\right\}-\text { sygnał sprzedaży, }
\end{gathered}
$$

gdzie:

$P_{t}$ - cena złota w momencie $t$,

$n$ - liczba okresów (dni), z których oblicza się poziomy wsparcia i oporu.

Dodatkowo przyjęto, że po wygenerowaniu sygnału kupna (sprzedaży) zajmowana pozycja inwestycyjna jest utrzymywana przez okres $10 \mathrm{dni}^{2}$, kiedy wszelkie

${ }^{2}$ Taki okres ,przetrzymania” przyjmuje się najczęściej w badaniach empirycznych (por. np. [Campbel 2011]). 
inne sygnały z rynku są ignorowane. W przypadku gdy odchylenie ceny złota od poziomów wsparcia czy oporu jest nieznaczne, to powstałe sygnały kupna lub sprzedaży uznaje się za słabe. W takiej sytuacji można stosować różne procedury ich odfiltrowania. W niniejszym artykule zastosowano do tego celu tzw. band - pasmo odchyleń od poziomów wsparcia i oporu. Zazwyczaj granicę tego pasma wyznacza się za pomocą arbitralnie przyjętego procentu wartości poziomu wsparcia czy oporu (np. 1\%) [Isakov i Hollistein 1999]. Sygnał kupna (sprzedaży) będzie generowany tylko wówczas, gdy cena złota będzie wyższa (niższa) od poziomu wsparcia (oporu) o więcej niż ustalony procent wartości tego poziomu. Reguły generowania sygnałów według przedstawionej tu zasady ilustrują wzory (3) i (4) [Campbel 2011]:

$$
\begin{gathered}
P_{t}>(1+b) \max \left\{P_{t-1}, P_{t-2}, \ldots, P_{t-n}\right\}-\text { sygnał kupna, } \\
P_{t}<(1-b) \min \left\{P_{t-1}, P_{t-2}, \ldots, P_{t-n}\right\}-\text { sygnał sprzedaży, }
\end{gathered}
$$

gdzie: $b$ - ustalony procent wartości poziomu oporu (wsparcia).

$\mathrm{W}$ artykule rozważano strategie zorientowane wyłącznie na kupno (strategia buy), sprzedaż (strategia sell), dystnas pomiędzy średnią ceną kupna i sprzedaży (strategia buy-sell) oraz strategię mieszaną uwzględniającą możliwość zajęcia dowolnej pozycji inwestycyjnej. Średnią warunkową stopę zwrotu z mieszanej strategii inwestycyjnej obliczono według wzoru [Isakov i Hollistein 1999]:

$$
\mu_{m}=\frac{1}{T} \sum_{t=1}^{T}\left(r_{t} d_{t}\right)
$$

gdzie:

$r_{t}$ - stopa zwrotu z inwestycji w złoto w momencie $t$,

$d_{t}-$ zmienna wskaźnikowa o wartościach: 1 (sygnał kupna), -1 (sygnał sprzedaży),

$T$ - całkowita liczba sygnałów kupna (sprzedaży).

Efektywność krótkoterminowych inwestycji w złoto zostanie zweryfikowana dzięki zastosowaniu testu istotności różnic $t$-Studenta dla warunkowych stóp zwrotu z poszczególnych strategii i oczekiwanej stopy zwrotu ${ }^{3}$. Stosowanie tego testu wymaga spełnienia kilku założeń przez rozkłady stóp zwrotu, w tym założenia o zgodności z rozkładem normalnym. W praktyce to założenie nie zawsze bywa spełnione, a wynik testu istotności może być obciążony błędem.

W związku z tym, aby zweryfikować rezultaty uzyskane na drodze klasycznego testu, przeprowadzono dodatkowo test efektywności poza próbą. Procedurę

${ }^{3}$ Dla strategii buy-sell $\mathrm{w}$ teście $t$-Studenta w hipotezie zerowej różnica między średnimi stopami zwrotu ze strategii „,kupuj i sprzedaj” jest przyrównana do zera. 
przedmiotowego testu przedstawiono m.in. w pracach [Cheung, Lam i Yeung 2007, 2011]. Polega ona na zastosowaniu optymalnego, pod względem zyskowności, systemu transakcyjnego w jednym okresie badawczym do generowania warunkowych stóp zwrotu w kolejnym okresie. Zatem najbardziej dochodowy system transakcyjny według przyjętej metody analizy technicznej w pierwszym roku okresu badawczego jest stosowany także w roku następnym. W kolejnym etapie procedury poszukuje się najbardziej dochodowego systemu transakcyjnego w pierwszych dwóch latach i następnie wybrany system wykorzystany jest do generowania warunkowych stóp zwrotu w trzecim roku itd. Postępowanie to jest kontynuowane aż do wyczerpania próby badawczej. W efekcie stosowanej procedury otrzymuje się nowe symulacyjne stopy zwrotu, które można porównywać $\mathrm{z}$ bezwarunkową średnią stopą zwrotu. Efektywność inwestycji w złoto w długim terminie oceniono z kolei, porównując wyniki inwestowania cyklicznego ze strategią „kup i trzymaj”.

\section{Wyniki badań empirycznych}

Metodę TRB testowano na historycznych cenach złota według danych pochodzących z fixingu w Londynie z okresu 2.01.1991-21.05.20134. Wykorzystując formuły (1)-(4), wygenerowano sygnały kupna oraz sprzedaży. Przy prezentacji wyników posłużono się następującym systemem oznaczeń: $(q, b)$, gdzie $q$ - okres, na podstawie którego wyznaczano punkty wsparcia i oporu (w dniach), $b-$ rozmiar pasma wahán wokół linii wsparcia i oporu (w \%) (por. [Brock, Lakonishok i LeBaron 1992]). Analizę przeprowadzono dla wybranych konfiguracji parametrów $q \in\{50,100,150,200\}$ oraz $b=\{0,1\}$. Wybór takich wartości parametrów odpowiada najczęściej spotykanym w podobnych badaniach długościom okresów stosowanych w obliczaniu poziomów wsparcia i oporu oraz rozmiarom pasma filtrującego słabe sygnały kupna oraz sprzedaży [Brock, Lakonishok i LeBaron 1992, Isakov i Hollistein 1999].

W tabeli 1 przedstawiono kształtowanie się liczby sygnałów kupna bądź sprzedaży w zależności od kombinacji parametrów $q$ i $b$ w metodzie TRB. Pod liczbą sygnałów kupna $\left(n_{b}\right)$ i sprzedaży $\left(n_{s}\right)$ podano odsetek prawidłowo zidentyfikowanych sygnałów. Sygnał kupna (sprzedaży) można uznać za poprawny, jeśli poprzedza on dodatnią (ujemną) warunkową stopę zwrotu.

Na podstawie danych zawartych w tabeli 1 można stwierdzić, że wzrost długości okresu stosowanego w obliczaniu poziomów wsparcia i oporu redukuje liczbę zarówno sygnałów kupna, jak i sygnałów sprzedaży. Ta prawidłowość

\footnotetext{
${ }^{4}$ Szereg czasowy obejmuje dzienne ceny złota w USD za 1 uncję trojańską (ok. 31,103 gramów).
} 
występuje niezależnie od stosowania pasma filtrującego. Odsetek poprawnie zidentyfikowanych sygnałów obu rodzajów oscyluje najczęściej w przedziale 50-60\% dla większości rozpatrywanych konfiguracji parametrów $q$ i $b$. Dodatkowo w sytuacji braku filtracji słabych sygnałów można zaobserwować tendencję do zmniejszania odsetka poprawnie zidentyfikowanych sygnałów kupna i sprzedaży przy równoczesnym wzroście wartości parametru $q$. Taka prawidłowość nie jest obserwowana, gdy słabe sygnały kupna i sprzedaży podlegają filtracji.

Tabela 1. Liczby wykrytych sygnałów kupna i sprzedaży w zależności od parametrów metody $\operatorname{TRB}(q, b)$

\begin{tabular}{|c|c|c|}
\hline \multirow{2}{*}{ Metoda } & \multicolumn{2}{|c|}{ Liczba sygnałów } \\
\cline { 2 - 3 } TRB $(q . b)$ & $n_{b}$ & $n_{s}$ \\
\hline \multirow{2}{*}{$(50,0)$} & 1235 & 965 \\
& $(58,14)$ & $(54,61)$ \\
\hline \multirow{2}{*}{$(100,0)$} & 890 & 583 \\
& $(61,35)$ & $(54,03)$ \\
\hline \multirow{2}{*}{$(150,0)$} & 740 & 433 \\
& $(61,89)$ & $(53,81)$ \\
\hline$(200,0)$ & 700 & 354 \\
& $(57,43)$ & $(52,54)$ \\
\hline$(10,1)$ & 761 & 372 \\
& $(56,64)$ & $(53,23)$ \\
\hline$(150,1)$ & 314 & 120 \\
& $(62,67)$ & $(51,72)$ \\
\hline$(200,1)$ & 430 & 172 \\
& $(63,72)$ & $(51,16)$ \\
\hline
\end{tabular}

Źródło: obliczenia własne.

Obliczone poziomy wsparcia i oporu wykorzystano następnie do wyznaczenia warunkowych średnich stóp zwrotu z inwestycji w złoto według strategii opartych na sygnałach kupna $\left(\mu_{b}\right)$, sygnałach sprzedaży $\left(\mu_{s}\right)$, strategii mieszanej $\left(\mu_{m}\right)$ oraz według strategii zorientowanej na różnicę $\left(\mu_{b}-\mu_{s}\right)$ (tabela 2$)$. W nawiasach pod średnimi stopami zwrotu umieszczono wartości $p$-value odpowiadające wynikom testu istotności różnic warunkowych średnich stóp zwrotu i oczekiwanej stopy zwrotu z inwestycji w złoto. 
Tabela 2. Warunkowe dzienne stopy zwrotu z inwestycji w złoto (w \%) i wyniki klasycznego testu istotności $t$-Studenta

\begin{tabular}{|c|c|c|c|c|}
\hline \multirow{2}{*}{$\begin{array}{c}\text { Parametry } \\
\text { metody TRB }\end{array}$} & \multicolumn{4}{|c|}{ Średnia stopa zwrotu } \\
\cline { 2 - 5 } & $\mu_{b}$ & $\mu_{s}$ & $\mu_{m}$ & $\mu_{b}-\mu_{s}$ \\
\hline \multirow{2}{*}{$(50,0)$} & 0,1930 & $-0,0922$ & 0,1508 & 0,2852 \\
& $(0,0000)$ & $(0,0014)$ & $(0,0000)$ & $(0,0000)$ \\
\hline \multirow{2}{*}{$(100,0)$} & 0,2152 & $-0,0888$ & 0,1681 & 0,3040 \\
& $(0,0000)$ & $(0,0171)$ & $(0,0000)$ & $(0,0001)$ \\
\hline \multirow{2}{*}{$(150,0)$} & 0,2045 & $-0,1134$ & 0,1742 & 0,3179 \\
& $(0,0002)$ & $(0,0120)$ & $(0,0001)$ & $(0,0006)$ \\
\hline \multirow{2}{*}{$(200,0)$} & 0,2064 & $-0,1127$ & 0,1780 & 0,3191 \\
& $(0,0003)$ & $(0,0258)$ & $(0,0001)$ & $(0,0021)$ \\
\hline \multirow{2}{*}{$(50,1)$} & 0,2246 & $-0,1132$ & 0,1907 & 0,3378 \\
& $(0,0001)$ & $(0,0679)$ & $(0,0001)$ & $(0,0052)$ \\
\hline \multirow{2}{*}{$(100,1)$} & 0,2706 & $-0,0808$ & 0,2141 & 0,3515 \\
& $(0,0001)$ & $(0,2976)$ & $(0,0005)$ & $(0,0259)$ \\
\hline \multirow{2}{*}{$(150,1)$} & 0,2549 & $-0,0889$ & 0,2107 & 0,3439 \\
& $(0,0008)$ & $(0,3502)$ & $(0,0022)$ & $(0,0652)$ \\
\hline \multirow{2}{*}{$(200,1)$} & 0,2602 & $-0,0096$ & 0,1935 & 0,2698 \\
& $(0,0008)$ & $(0,7860)$ & $(0,0058)$ & $(0,1691)$ \\
\hline
\end{tabular}

Źródło: obliczenia własne.

$\mathrm{Z}$ danych zamieszczonych $w$ tabeli 2 wynika, że stosując strategię inwestycyjną zorientowaną wyłącznie na kupno złota, najwyższą przeciętną warunkową stopę zwrotu mógł osiągnąć inwestor wykorzystujący 100-dniowy okres dla ustalania poziomów wsparcia i oporu z filtracją słabych sygnałów kupna i sprzedaży. Jego średnia dzienna stopa zwrotu wyniosłaby $0,2706 \%$, co daje roczną stopę zwrotu w wysokości ok. 96,72\%. Najniższy dochód inwestora zorientowanego na kupno złota inwestycyjnego przynosiłoby natomiast stosowanie 50-dniowego okresu obliczania poziomów wsparcia i oporu bez filtracji słabych sygnałów. Z kolei inwestor posługujący się wyłącznie strategią „,sprzedaj” najwyższą bezwzględną roczną stopę zwrotu wynoszącą ok. 32,78\% mógł zrealizować, stosując metodę TRB z parametrami $(150,0)$, natomiast najniższą bezwzględną średnią stopę zwrotu $(2,42 \%$ w skali roku) uzyskałby inwestor posługujący się metodą TRB z parametrami $(200,1)$. W przypadku stosowania strategii mieszanej, podobnie jak przy strategii „kupuj”, najwyższą przeciętną stopę zwrotu zrealizowałby inwestor stosujący technikę TRB z parametrami $(100,1)(70,77 \%$ w skali roku), a na zrealizowanie najniższej przeciętnej stopy zwrotu może liczyć inwestor stosujący parametry $(50,0) \mathrm{w}$ metodzie TRB $(45,78 \% \mathrm{w}$ skali roku). W sytuacji braku filtracji słabych sygnałów kupna i sprzedaży najwyższą przeciętną stopę 
zwrotu dla strategii opartej na różnicy $\mu_{b}-\mu_{s}$ inwestor mógł zrealizować, stosując system transakcyjny $(200,0)$, a przy wprowadzeniu takiej filtracji - stosując system $(100,1)$. Odpowiednie wartości średnich dziennych stóp zwrotu wynoszą wówczas 0,3191\% (122,1\% w skali roku) i 0,3515\% (140,8\% w skali roku). Z tabeli 2 wynika również, że wprowadzeniu filtracji sygnałów kupna i sprzedaży, podobnie jak zwiększaniu wartości parametru $q$, zazwyczaj towarzyszy wzrost warunkowych średnich stóp zwrotu. Wszystkie warunkowe stopy zwrotu w strategii „kupuj” oraz w strategii mieszanej są statystycznie istotnie wyższe od oczekiwanej stopy zwrotu (szacowanej za pomocą średniej dziennej stopy zwrotu) na poziomie istotności 0,05. Taka sytuacja ma również miejsce w zakresie strategii „sprzedaj”, ale tylko w przypadku braku filtracji słabych sygnałów kupna i sprzedaży. W pozostałych przypadkach bezwzględne stopy zwrotu dla tej strategii nie różnią się istotnie od oczekiwanej stopy zwrotu z inwestycji w złoto. Ponieważ jednak założenia dotyczące testu $t$-Studenta co do normalności rozkładu stóp zwrotu nie są spełnione (m.in. wskutek występowania asymetrii i silnej leptokurtyczności rozkładu stóp zwrotu), przedstawione wyniki mogą być obciążone błędem ${ }^{5}$.

Tabela 3. Symulacyjne warunkowe dzienne stopy zwrotu z inwestycji w złoto (w \%) i wyniki testu poza próbą

\begin{tabular}{|c|c|c|c|c|}
\hline \multirow{2}{*}{$\begin{array}{c}\text { Parametry } \\
\text { metody TRB }\end{array}$} & \multicolumn{4}{|c|}{ Symulacyjna warunkowa stopa zwrotu } \\
\cline { 2 - 5 } & $\mu_{b}$ & $\mu_{s}$ & $\mu_{m}$ & $\mu_{b}-\mu_{s}$ \\
\hline \multirow{2}{*}{$(50,0)$} & 0,0686 & $-0,0510$ & 0,0249 & 0,1196 \\
& $(0,0443)$ & $(0,2670)$ & $(0,0120)$ & $(0,0879)$ \\
\hline \multirow{2}{*}{$(100,0)$} & 0,1336 & 0,1221 & 0,0477 & 0,0115 \\
& $(0,2739)$ & $(0,3292)$ & $(0,3631)$ & $(0,5518)$ \\
\hline \multirow{2}{*}{$(150,0)$} & 0,2140 & $-0,2002$ & 0,0486 & 0,4142 \\
& $(0,0003)$ & $(0,0001)$ & $(0,0444)$ & $(0,0000)$ \\
\multirow{2}{*}{$(200,0)$} & 0,0717 & 0,5428 & $-0,0375$ & $-0,4711$ \\
& $(0,9029)$ & $(0,4095)$ & $(0,7758)$ & $(0,5298)$ \\
\multirow{2}{*}{$(50,1)$} & 0,1917 & $-0,1875$ & 0,0423 & 0,3791 \\
& $(0,0030)$ & $(0,0590)$ & $(0,0083)$ & $(0,0164)$ \\
\hline \multirow{2}{*}{$(100,1)$} & 0,1567 & $-0,1250$ & 0,0149 & 0,2816 \\
& $(0,0114)$ & $(0,1704)$ & $(0,0740)$ & $(0,0065)$ \\
\hline \multirow{2}{*}{$(150,1)$} & 0,4175 & 0,3225 & 0,0331 & 0,095 \\
& $(0,0088)$ & $(0,4471)$ & $(0,0075)$ & $(0,1918)$ \\
\hline \multirow{2}{*}{$(200,1)$} & 0,3455 & 0,2509 & 0,0733 & 0,0946 \\
& $(0,7523)$ & $(0,3865)$ & $(0,6912)$ & $(0,1254)$ \\
\hline
\end{tabular}

Źródło: obliczenia własne.

${ }^{5}$ Stosowanie testu $t$ istotności różnic średnich wymaga spełnienia założenia m.in. o normalności rozkładu zmiennych losowych. 
W związku z tym przeprowadzono dodatkowy test efektywności poza próbą, który pozwolił na zweryfikowanie rezultatów uzyskanych na drodze tradycyjnych testów statystycznych. Samą procedurę symulacji szczegółowo przedstawiono w punkcie 2 niniejszego opracowania.

Tabela 3 przedstawia wyniki testu efektywności poza próbą dla wszystkich rozważanych systemów transakcyjnych (w nawiasach podano prawdopodobieństwa testowe).

Symulacyjne prawdopodobieństwa testowe w tabeli 3 mniejsze od 0,05 nie pozwalają na wyjaśnienie znacząco wysokich (niskich) wartości średnich warunkowych stóp zwrotu z inwestycji w złoto dla strategii kupna (sprzedaży), strategii mieszanej oraz dla strategii opartej na różnicy między ceną kupna i sprzedaży.

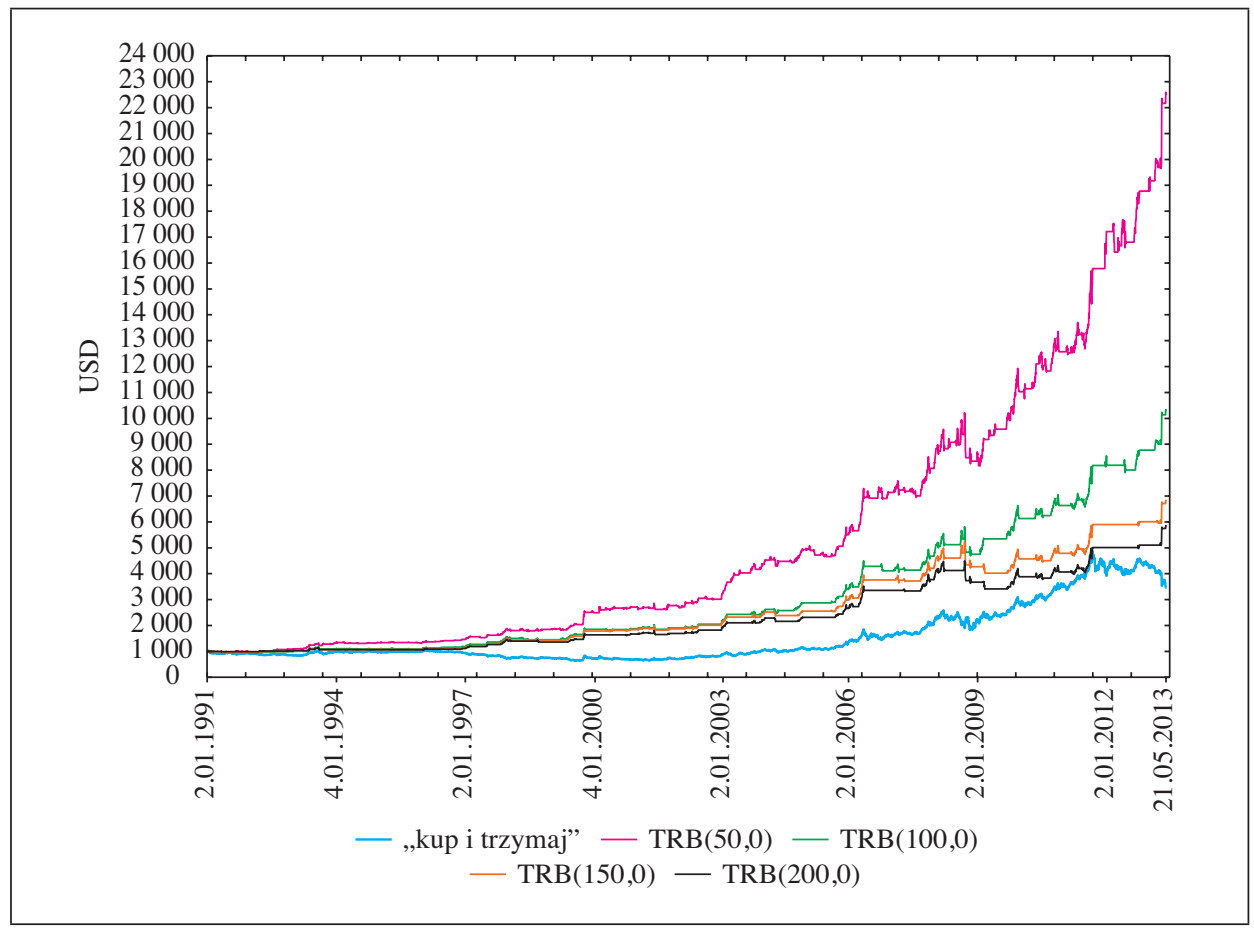

Rys. 1. Wartość inwestycji 1000 USD ulokowanej w złoto według strategii mieszanej wykorzystującej metodę TRB bez filtracji sygnałów kupna i sprzedaży i według strategii „kup i trzymaj” w okresie 2.01.1991-21.05.2013

Źródło: opracowanie własne.

Statystycznie istotne wyniki w teście poza próbą oraz w teście $t$-Studenta uzyskano w analogicznych strategiach inwestycyjnych, stosując trzy systemy transakcyjne: $(150,0),(50,1)$ i $(150,1)$. W przypadku metody TRB z parametrami 
$(50,0)$ oraz $(100,1)$ wyniki symulacyjnego $p$-value również są zgodne z rezultatami uzyskanymi za pomocą klasycznych testów istotności, ale w odniesieniu tylko do niektórych strategii inwestycyjnych. W omawianych tu przypadkach trudno więc wyjaśnić ponadprzeciętne stopy zwrotu np. brakiem spełnienia założeń co do normalności stóp zwrotu, niezmienności w czasie rozkładu stóp zwrotu itp. Interesujące są przypadki pozostałych rozważanych systemów transakcyjnych, jak np. $(100,0)$ i $(200,0)$, w których symulacyjne stopy zwrotu nie różniły się istotnie od oczekiwanych stóp zwrotu (niezależnie od strategii inwestycyjnej). Biorąc pod uwagę fakt, że w tych sytuacjach wyniki klasycznego testu $t$-Studenta były statystycznie istotne, można przyjąć, że naruszenie założeń co do normalności stóp zwrotu mogło być jedną z przyczyn ponadprzeciętnych zysków z inwestycji w złoto.

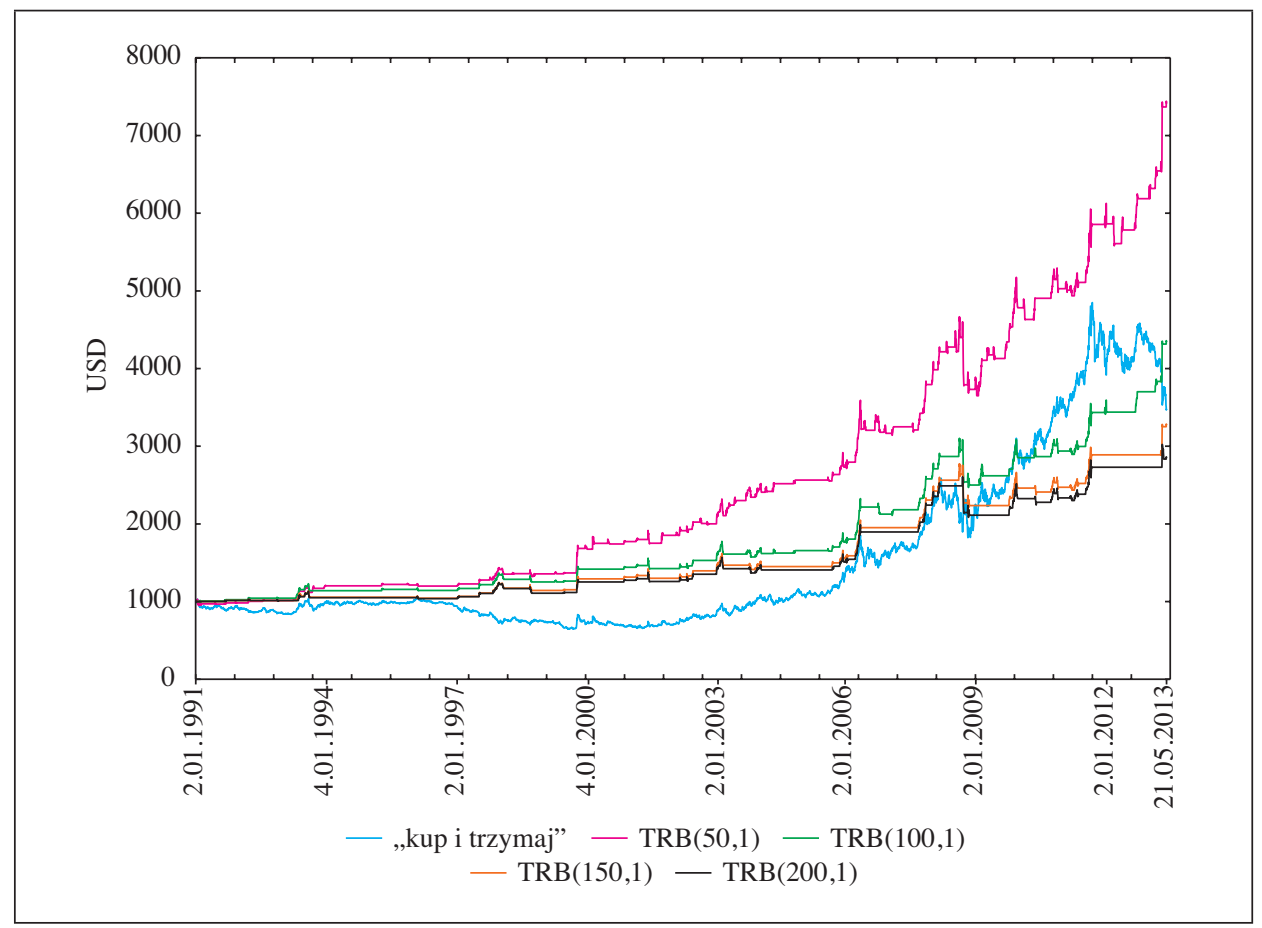

Rys. 2. Wartość inwestycji 1000 USD ulokowanej w złoto według strategii mieszanej wykorzystującej metodę TRB z filtracją sygnałów kupna i sprzedaży i według strategii „kup i trzymaj” w okresie 2.01.1991-21.05.2013

Źródło: opracowanie własne.

W ocenie efektywności długoterminowej inwestycji w złoto istotne wydaje się porównanie wyników inwestowania cyklicznego ze strategią „kup i trzymaj”. Jeśli 
stosowana metoda analizy technicznej jest bardziej zyskowna niż strategia „kup i trzymaj", to można uznać ją za efektywną.

Na rys. 1 przedstawiono kształtowanie się wartości początkowej inwestycji wynoszącej 1000 USD ulokowanej według dwóch strategii: mieszanej wykorzystującej metodę TRB bez filtracji sygnałów kupna i sprzedaży oraz strategii „kup i trzymaj" w okresie 2.01.1991-21.05.2013.

$\mathrm{Z}$ rys. 1 wynika, że w sytuacji braku filtracji słabych sygnałów kupna i sprzedaży najkorzystniejszą strategią inwestycyjną w długim okresie jest metoda zasięgu przebicia z 50-dniowym okresem obliczania punktów wsparcia i oporu. Wartość inwestycji zgodnej z tą strategią w dniu 21 maja 2013 r. wyniesie ok. 22493 zł i będzie ponad sześciokrotnie wyższa od wartości inwestycji bazującej na strategii „kup i trzymaj”. Wzajemne położenie krzywych na rys. 1 wskazuje, że metoda TRB $(q, b)$ w długim okresie zapewniała zawsze wyższy dochód $\mathrm{z}$ inwestycji w złoto w porównaniu ze strategią „kup i trzymaj”, przy czym dochód ten był tym wyższy, im wyższą wartość miał parametr $q$. Rys. 2 przedstawia wartość inwestycji zgodnej z metodą TRB z uwzględnieniem filtracji sygnałów kupna i sprzedaży oraz inwestycji zgodnej z metodą „kup i trzymaj”.

Inwestor stosujący filtrację słabych sygnałów kupna i sprzedaży (rys. 2) w dalszym ciągu najwyższy dochód osiągnąłby, stosując metodę zasięgu przebicia z 50-dniowym okresem wyznaczania punktów wsparcia i oporu. W dniu 21 maja 2013 r. wartość inwestycji bazującej na tej strategii wyniosła ok. 7411 zł i była o blisko $113 \%$ wyższa od wartości inwestycji zgodnej ze strategią „kup i trzymaj”. Strategia „kup i trzymaj” była najmniej zyskowna do 2008 r., ale w kolejnych latach była bardziej zyskowna niż strategia bazująca na metodzie TRB z parametrem $q$ równym 100, 150 i 200. Jedynie od połowy kwietnia 2013 r. wyższą dochodowość od strategii „kup i trzymaj” (poza strategią opartą na metodzie TRB $(50,1))$ osiągnęła strategia TRB $(100,1)$. Wartość inwestycji zgodnej z metodą TRB $(100,1)$ w dniu 21 maja 2013 r. wyniosła 4341 zł i była o ok. 25\% wyższa od wartości inwestycji zgodnej ze strategią „kup i trzymaj”. Uwagę zwraca też fakt, że w przypadku opcji filtracji słabych sygnałów występuje ujemna korelacja pomiędzy wartościami parametru $q$ a poziomem zyskowności strategii $\operatorname{TRB}(q, b)$.

\section{Podsumowanie}

W artykule wykorzystano narzędzia analizy technicznej do zbadania, czy możliwe jest zrealizowanie ponadprzeciętnych zysków z inwestycji w złoto w krótkim, a także w długim okresie. W świetle otrzymanych rezultatów badań przy odpowiednich scenariuszach inwestycyjnych potwierdzono taką możliwość. Stwierdzono dodatkowo, że stosowanie jednoprocentowego odchylenia od 
poziomów wsparcia i oporu, jak też zwiększanie wartości parametru $q$ w stosowanej metodzie TRB powoduje wzrost przeciętnej warunkowej stopy zwrotu. Badania potwierdziły również efektywność inwestycji w złoto w długim terminie w zestawieniu ze strategią „kup i trzymaj”. Odpowiedni dobór parametrów metody zasięgu przebicia pozwala wypracować wyższą zyskowność inwestowania cyklicznego w porównaniu ze strategią „kup i trzymaj”. Przewaga stosowanej metody analizy technicznej jest szczególnie widoczna w sytuacji braku filtracji słabych sygnałów kupna i sprzedaży.

Do przedstawionych wyników należy podchodzić z pewną dozą ostrożności, gdyż nie uwzględniają one dodatkowych kosztów związanych np. z przechowywaniem, ochroną czy ubezpieczeniem zakupionego złota, jak również ryzyka kursowego walut, w których denominowana jest cena złota.

Zastosowanie testu efektywności poza próbą pozwoliło na zweryfikowanie wyników uzyskanych za pomocą klasycznego testu $t$-Studenta. Wyniki porównań obu testów pod względem statystycznej istotności otrzymanych rezultatów są tylko częściowo zgodne. W związku z tym z jednej strony w przypadku niektórych systemów transakcyjnych przyczyną ponadprzeciętnych dochodów z inwestycji w złoto mogło być niespełnienie warunków normalności rozkładów stóp zwrotu. Z drugiej zaś strony w przypadku innych scenariuszy inwestycyjnych wyniki testów efektywności poza próbą nie wyjaśniły ponadprzeciętnych stóp zwrotu. Trudno też w sposób jednoznaczny stwierdzić, czy różnice w poziomie ryzyka związane z poszczególnymi strategiami były przyczyną ponadprzeciętnych zysków z inwestycji w złoto. Tym samym hipotezy o efektywność rynku złota inwestycyjnego w słabym sensie nie można w pełni odrzucić, jak też nie można jej w pełni potwierdzić. Wydaje się zatem, że przedstawione wyniki mogą być również inspiracją do dalszych badań nad efektywnością inwestycji w złoto, np. przy zastosowaniu innych narzędzi analizy technicznej.

\section{Literatura}

Bachowski C., Kudełko J., Wirth H. [2011], Ocena światowego rynku górniczych projektów zasobowych metali nieżelaznych, ,Zeszyty Naukowe Instytutu Gospodarki Surowcami Mineralnymi i Energii Polskiej Akademii Nauk", nr 81.

Borowski K. [2008], Rynek złota i monet [w:] Inwestycje alternatywne, red. I. Pruchnicka-Grabias, CeDeWu, Warszawa.

Brock W., Lakonishok J., LeBaron B. [1992], Simple Technical Trading Rules and the Stochastic Properties of Stock Returns, ,Journal of Finance”, vol. 47, http://dx.doi. org/10.1111/j.1540-6261.1992.tb04681.x.

Campbel H.M. [2011], Simple Technical Trading Rules on the JSE Securities Exchange of South Africa, Part 2, „Proceedings of the World Congress on Engineering”, vol. 1.

Chang E.J. i in. [2004], Testing for Predictability in Emerging Equity Markets, „Emerging Markets Review", vol. 5, http://dx.doi.org/doi:10.1016/j.ememar.2004.03.005. 
Cheung W., Lam K.S.K., Yeung H.F. [2007], The Profitability of Simple Technical Trading Strategies: The Case of Hong Kong, Working Papers Series, http://papers.ssrn. com/sol3/papers.cfm?abstract_id=1008740\#\# (data dostępu: 21.07.2014).

Cheung W., Lam K.S.K., Yeung H.F. [2011], Intertemporal Profitability and the Stability of Technical Analysis: Evidences from the Hong Kong Stock Exchange, „Applied Economics", vol. 43, http://dx.doi.org/10.1080/00036840902817805.

Coutts J.A. [2010], Trading Rules and Stock Returns: Some Further Short Run Evidence from the Hang Seng 1997-2008, ,Applied Financial Economics”, vol. 20, nr 21, http:// dx.doi.org/10.1080/09603107.2010.524613.

Coutts J.A., Cheung K. [2000], Trading Rules and Stock Returns: Some Preliminary Short Run Evidence from the Hang Seng 1985-1997, ,Applied Financial Economics”, vol. 10.

Duke F. [2004], Understanding the Precious in Metals, „Futures”, Stock, Commodity, Options and Forex Strategies for the Modern Trader, The Alpha Pages Magazine.

Filipowicz E. [2010], Inwestycje w złoto jako alternatywna forma lokowania kapitałów na rynku polskim, Zeszyty Naukowe Uniwersytetu Szczecińskiego, „Finanse. Rynki Finansowe. Ubezpieczenia", nr 29.

Górska A. [2011], Zastosowanie narzędzi analizy technicznej w bezpośrednim i pośrednim inwestowaniu w towary, Zeszyty Naukowe SGGW w Warszawie, „Problemy Rolnictwa Światowego", vol. 11, nr 26.

Hudson R., Dempsey M., Keasey K. [1996], A Note on the Weak Form Efficiency of Capital Markets: The Application of Simple Technical Trading Rules to UK Stock Prices - 1935 to 1964, ,Journal of Banking and Finance”, vol. 20.

Isakov D., Hollistein M. [1999], Application of Simple Technical Trading Rules to Swiss Stock Prices: Is It Profitable? „Financial Markets and Portfolio Management”, vol. 13, nr 1.

Lee Y.M. i in. [2013], Does Gold Act as Inflation Hedge in the USA and Japan? „Transformations in Business \& Economics", vol. 12, nr 2(29).

Mensi W. i in. [2013], Correlations and Volatility Spillovers across Commodity and Stock Markets: Linking Energies, Food, and Gold, Munich Personal RePEc Archive, Paper No. 44395, posted 12.

Pring M.J. [1998], Podstawy analizy technicznej, WIG-Press, Warszawa.

Singh R.P., Kishor N. [2014], Co-Integration of Gold Price Movement with Nifty Indices: A Study in Indian Context, ,Transnational Corporations Review”, vol. 6, nr 1.

\section{Study on the Effectiveness of Investments in Gold Using a Method TRB}

Buying gold is considered a relatively sure capital investment, because the purchasing power of this metal generally does not decrease over time. The question is whether and to what extent investment in gold can be profitable in the short term. This paper seeks to answer that question. In so doing, it investigates whether technical trading rules are effective in researching gold prices and whether it is possible to achieve above average profits in a short time horizon. The research takes into consideration Trading Range Break (TRB) rules. The results will allow the distributions of conditional return on an investment in gold to be identified. The effectiveness of investments in gold were analysed by the following means: using the $t$-Student and out-of-sample tests and comparing TRB with ,buy and hold" method.

Keywords: gold, financial investments, technical analysis, Student's $t$-test. 